\title{
Transnational Corporations, Natural Resources and Conflict
}

\author{
Professor Solomon E. Salako ${ }^{1}$ \\ ${ }^{1}$ Liverpool Hope Business School and Archbishop Desmond Tutu Centre for War and Peace Studies, Liverpool \\ Hope University, Liverpool, United Kingdom \\ Correspondence: Professor Solomon E. Salako, Liverpool Hope Business School and Archbishop Desmond Tutu \\ Centre for War and Peace Studies, Liverpool Hope University, Liverpool, United Kingdom. E-mail: \\ salakos@hope.ac.uk
}

Received: April 22, 2020

Accepted: May 26, 2020

Online Published: July 3, 2020

doi:10.5539/ilr.v9n1p56

URL: https://doi.org/10.5539/ilr.v9n1p56

\begin{abstract}
Transnational Corporations (TNCs) exploit natural resources, whether renewable as in the case of forests, fisheries and agricultural products or non-renewable as in the case of minerals or petroleum, in developing countries through their subsidiaries. TNCs' exploitation of forests and acquisition of intellectual property rights in plants and animal breeding, based on the traditional knowledge of indigenous peoples developed over millennia, are in conflict with the rights of indigenous peoples to their territories, resources and traditional knowledge. TNCs also profit from conflict by trading natural resources that prolong wars; colluding with repressive governments to pervert political processes within a State; aiding and abetting crimes against humanity; and flagrantly violating human rights. This article explores the areas of conflict outlined above and examines the efficacy of the mechanisms for the control of TNCs whether legally binding or not. It is suggested that the only effective way of making TNCs accountable for their human rights violations and aiding and abetting crimes against humanity is the establishment of an international court with jurisdiction over corporations.
\end{abstract}

Keywords: transnational corporations, natural resources, conflict, corporate social responsibility, international law

\section{Introduction}

The history of Transnational Corporations (TNCs) is the history of exploitation of natural resources in developing countries and conflict and the failure to make TNCs accountable for collusion with repressive governments to pervert political processes within a State, egregious breaches of human rights and aiding and abetting crimes against humanity.

TNCs, that is, corporations whether incorporated or state-owned, which own or control production or service facilities outside the country in which they are based are not recent post-World War II creation as some theorists suggest (Vagts, 1970). The first TNC was the Dutch East India Company (or Vereenidge Oost-Indiche Companie (VOC)) founded in 1602. The company was responsible for the Batavia Massacre of 1740 during the Chinese uprising over prices of sugar. In 1798, the company, weakened by internal deficiencies in the face of its competitors, notable among which was the British East India Company, was dissolved (Kelly, 2018).

The quest for natural resources by European powers in order to benefit the home countries led to widespread colonial activity during the Age of Discovery or the Age of Exploration (early $15^{\text {th }}$ century to early $17^{\text {th }}$ century) and after. For each possession acquired there was a corporation established as an instrument of annexation such as the British East India Company (the largest), Hudson Bay Company and the National African Company founded in 1879, to mention a few. In 1886 the National African Company was granted a Royal Charter under the name of Royal Niger Company, Chartered and Limited, which authorised the Company to administer the district obtained by cession and to exercise sovereign rights over the Protectorate of Northern Nigeria but with the proviso that "[t]he Company shall always be and remain British in character and domicile; and shall have its principal office in England ... and all Directors shall be natural born British" (Cook, 1964; Elias, 1967). It is worthy of note that limited liability was introduced by the Limited Liability Act 1855 and TNCs' accountability for their wrongs is based on the concept of corporate personality - that a corporation is a legal persona (a legal personality) distinct from the personalities of persons who constitute it - enunciated in 1897 in the decision of the House of Lords in the United Kingdom in Salomon v Salomon \& Co (Note 1). On 1 January 1900, the 
British Government took over the entire territory of the Royal Niger Company, Chartered and Limited; thus annexing Northern Nigeria.

The quest for natural resources for the benefit of the home State, a hangover from the Age of Discovery, alluded to above, is one aspect of the exploitation of natural resources by TNCs in developing countries; the other aspect is neoliberalism. In the 1970s and 1980s, neoliberalism was constructed by democratic means in some countries and, in others, in the case of Chile, brute force and repression of all solidarity within labour and social movements. The principles espoused by neoliberals are liberalisation of the market and finance, deregulation, macroeconomic stability (end inflation), privatisation, and the withdrawal of the State from many areas of social provision, and the destruction of all forms of social solidarity such as trade unions. The propagation of neoliberalism worldwide is the result of powerful governments, especially the United States, the creation of the World Trade Organization in the 1990s and through the operations of the IMF, the World Bank and TNCs (Chomsky, 1999; Harvey, 2011).

TNCs exploit natural resources, whether renewable as in the case of forests, fisheries and agricultural products or non-renewable as in the case of minerals or petroleum. Where neoliberal states in developing countries take the side of TNCs, conflict is inevitable. TNCs' exploitation of forests and acquisition of intellectual property rights in plant and animal breeding, based on the traditional knowledge of indigenous peoples developed over millennia, are in conflict with the rights of indigenous peoples to their territories, biogenetic resources and traditional knowledge. TNCs profit from conflict by trading natural resources that prolong wars, collude with repressive governments to pervert political processes within a State, and are responsible for egregious violations of human rights and aiding and abetting crimes against humanity. Legal and social theorists have analysed TNCs and their exploitation of natural resources in developing countries. The point, however, in this article is to show that the only effective way of making TNCs accountable for their human rights violations and aiding and abetting crimes against humanity is the establishment of an international court with jurisdiction over corporations.

In this article, the themes to be discussed are as follows:

(i) Transnational Corporations in Conflict Regions: neoliberalism versus resource sovereignty or autochthony;

(ii) The impact of Transnational Corporations on indigenous peoples;

(iii) A critical analysis of corporate social responsibility;

(iv) The (in)efficacy of mechanisms for regulating Transnational Corporations; and

(v) Conclusions: the desirability and feasibility of an international court with jurisdiction over corporations.

But first, TNCs in conflict regions are critically assessed in a lexical order.

\section{TNCs in Conflict Regions: Neoliberalism versus Resource Sovereignty or Autochthony}

It is estimated that there are almost 60,000 TNCs worldwide in over 70 conflict regions (Bais and Huijser, 2005). Although TNCs are prohibited from engaging directly or indirectly in violations of $j u s$ cogens principles such as the prohibition of slavery and forced labour, genocide, torture, extrajudicial murders and crimes against humanity, globalisation has given them unprecedented economic, political and environmental power - compendiously described as "market power" - to influence illegitimately the political process within a State, undermine democracy, aid and abet crimes against humanity and flagrantly violate human rights.

While the atrocities committed by TNCs in their exploitation of non-renewable resources (minerals or petroleum) are egregious, the wrongs committed in the exploitation of renewable resources (forests, fisheries and agricultural products) are civil, not criminal, wrongs and will be discussed later; but first, the exploitation of minerals is critically assessed. The United Nations Conference on Trade and Development (UNCTAD) classified the extractive industry into three main categories: (i) energy minerals (oil, gas, coal and uranium); (ii) metallic minerals (ferrous metals, precious metals and base metals); and (iii) non-metallic minerals (construction minerals, industrial minerals and precious stones) (UNCTAD, 2008). These categories are sub-divided and are rather cumbersome for the analysis of TNCs' exploitation of minerals in conflict regions. To facilitate exposition, non-renewable minerals in conflict regions are classified as (i) blood diamonds, (ii) conflict minerals or "3Ts + G" (tantalum, tin, tungsten and gold), (iii) petroleum, and (iv) others. There are, however, two points of conflict between TNCs and developing countries to be discussed. The first is the introduction of neoliberal programmes in developing countries and the second is that TNCs profit in trading in natural resources that prolong wars.

\subsection{Neoliberalism versus Resource Sovereignty or Autochthony}

Conflicts over the extraction of minerals are shaped by two opposing principles: (i) neoliberalism, and (ii) 
resource sovereignty or autochthony (Note 2). Neoliberalism - free trade and privatisation - is foisted on developing countries by powerful governments making false promises of local economic development. This often leads to the handover of the developing country's natural resources to TNCs. The opposing principle is resource sovereignty or autochthony: the right of the people to natural resources situated in their territories and to adopt economic and political systems that are autochthonous, that is, home-grown or home-bred or indigenous to their soil. When these two principles collide, conflict is inevitable. To illustrate this collision, four case studies will suffice.

The first is Chile. When Salvador Allende lost the presidency to Eduardo Frei in 1964, before Chile embraced neoliberalism, there was a national consensus that the copper industry should be subjected to some form of state ownership or control. Copper was of strategic importance to Chile because of the foreign exchange earnings and was also a strategic input for TNCs because it was basic to their system of producing and capital accumulation. The demand for copper arose out of the growth of electric power industry in the United States. The Chilenization of copper inevitably became a conflict between Allende's Chile and American capitalism and the imperialist intervention on behalf of the TNCs 'expropriated' led to the bloody overthrow and killing of Allende, a democratically elected President. A few weeks after Allende's demise the Chilean subsidiaries of TNCs 'expropriated' were ready to resume their exploitation of copper in Chile (Girvan, 1976).

The second is Bolivia. The Bolivia Guera del Gas or the Gas War of 2003 - a discontent with neoliberalism had been brewing since the introduction of neoliberalism in Bolivia in the mid-1980s. The proximate cause of the war was the formation of Pacific LNG: a consortium involving Repsol YPF, British Gas and Pan-American Energy formed in Paris in 2002. The Bolivian Government in collaboration with the consortium planned to transport natural gas from its Margarita gas field via a pipeline to a plant in the Chilean coast and to be transformed into liquefied gas (LNG) and shipped to the United States and Mexico. (Bolivia is landlocked because it lost its coastal region to Chile in the War of Pacific in the 1870s.) What began as calls to export gas through a Peruvian port rather than a Chilean port became a violent protest which led to the death of seventy Bolivians and President Ganzalo Sánchez resigning and fleeing to the United States (Sawyer and Gomez, 2012).

The third is the Philippines. The Philippines rank globally second in gold, third in copper, fifth in nickel and six in chromite. How does it exercise its resource sovereignty or autochthony? The Mining Act 1985 gives the government the right to grant mining rights to individuals and corporations. Pursuant to this Act, local corporations and TNCs are given rights to use water and forest resources without permission from the indigenous peoples. The TNCs are even allowed to repatriate $100 \%$ of their profits. This was challenged in court by a tribal association on the grounds that it violated Article XII of the Philippine Constitution of 1987 which stipulated that the State may enter into a joint venture or production sharing agreement with Filipino citizens or corporations or associations at least 60 per cent of whose capital is owned by such citizens, corporations or associations and that the agreement to repatriate 100 per cent profit was therefore unconstitutional, null and void, and of no effect whatsoever. The Supreme Court of the Philippines deferred to the neoliberal state and TNCs, favouring 100 per cent of foreign ownership instead of 40 per cent share (Sawyer and Gomez, 2012).

The fourth is the proposal to exploit coal by AEC, a British mining company in Phulbari, a densely populated agricultural area of Bangladesh, by building a coal mine if it received government approval. The local community and transnational activists resisted on two grounds: (i) that the open mine would destroy the agricultural land and underground water resources; and (ii) that the narratives assuming the benefits to the community were unconvincing. The coal mine project was cancelled (Faruque, 2018).

\subsection{Blood Diamonds and Conflict Minerals}

The history of "blood diamond" and "conflict minerals" is inextricably intertwined with civil wars in Liberia and Sierra Leone in West Africa and the Democratic Republic of the Congo (DRC) in Central Africa. Liberia played a vital role in the outbreak of civil war in Sierra Leone and under Charles Taylor's leadership, Liberia became a pariah state due to his use of blood diamonds to fund the civil war in Sierra Leone, a country which relies on the mining of diamond for its economic base. ABN Amro (the fourteenth on the world list of diamond banks) did not invest in Sierra Leone but granted loans to diamond traders some of whom buy their raw materials from the Revolutionary United Front in Sierra Leone led by Foday Sankoh who in turn used the proceeds of sale to buy new loads of Kalashnikovs. Congo is perhaps the richest African country in mineral wealth. 80 per cent of the reserves of coltan, which is a major source of tantalum used as a high-charge conductor for mobile phones, digital games, microprocessors and associated products, lie in the eastern region of Congo. This country is also home to a considerable proportion of minerals such as gold, diamonds, uranium, copper, tin which is processed from cassiterite and tungsten which is used to construct lightbulbs, laptop screens and make cell phones vibrate 
( Smith,2011).

In 1960, at the time of the constitutional crisis in Congo, Société Générale de Belgique (SGB), a TNC, owned Union Minère de Haute Katanga (UMHK), its subsidiary, which owned or controlled most of the non-renewable natural resources in the Congo. As a matter of fact, SGB's operation accounted for 70 per cent of the Congolese economy. Pursuant to resource sovereignty or autochthony, Joseph Mobutu declared 'economic independence' in 1966 and expropriated the assets of UMHK which was later renamed Celamines (McKern, 1993). The aversion of the Western powers to communism influenced their support for Mobutu who, before he was driven out of Congo by Laurent Dèsirè Kabila and his allies, plundered the Treasury of Congo by asserting what is known as "resource privilege" (Pogge, 2013). The war to overthrow Mobutu was the first recent civil war fought in Congo between 1996 and 1997. The second civil war started in 1998 by erstwhile allies of Kabila with a view to taking over the natural resources of the country. During the hostilities, warlords and militias used forced labour to extract both diamonds and conflict minerals which were bought by high-level middlemen (comptoirs or accountants) who sold them to Belgians, South Africans, Rwandans and other foreigners who in turn sold them to buyers in the United States, Japan and Europe; and TNCs have negotiated directly with ruthless militias and warlords who forced people to mine diamonds and conflict minerals, plundered villages and used rape as an instrument of war (Mantz, 2008; Smith, 2011).

The link between diamonds and war was first recognised by the United Nations Resolution 1173 of June 1998 (Note 2). Since then, the persistent question has been whether the illegal exploitation of diamonds and conflict minerals can be stopped; and, if so, whether the mechanisms adopted are efficacious or not. The mechanisms are discussed later but it is pertinent to note that the obstacles to a lasting solution are the artisanal or small diamond and "3Ts + G" miners and the voluntary private-public cooperation - the logic of the Kimberley process (discussed later) which cannot be used in the DRC because of weak internal controls (Turner, 2013). DRC is not the only diamond producer in the Great Lakes Region of Africa. The marketing of diamonds in Angola is also problematic. In Angola, all rights to Angolan diamonds were granted to ASCorp - a joint venture between the state diamond company, SODIAM, Willcox of Israel and Tars of Belgium - financed by Lev Levi, an Israeli-Russian businessman and the biggest buyer on the diamond market outside De Beers, a TNC founded in South Africa with its marketing arm, the Diamond Trading Company, resident in London, in the United Kingdom.

Angola signed a structural agreement in March 2000 with Belgium's Diamond High Council which operates on behalf of the diamond industry and Belgian Ministry of Economic Affairs to ensure that its diamonds are 'clean'. However, the Angolan market is divided into three sectors: (i) the formal market which consists of diamonds officially licensed by ASCorp; (ii) the informal market which consists of diamonds mined "freelance" and sold to buyers licensed by ASCorp; and (iii) the illicit sector mined by unlicensed diggers and buyers (Tamm, 2002). It is therefore safe to assert that there is a rebuttable presumption that "blood diamonds" and "conflict minerals" are still being traded and TNCs profit from trading in these resources which prolong wars and are complicit in the heinous crimes perpetrated by warlords and militias in the conflict region.

\subsection{Transnational (Oil) Corporations' Violations of Human Rights}

The petroleum or oil industry is an oligopoly dominated by a few large sellers. The eleven major oil TNCs (with their states of origin and revenue in 2018) are as follows:

1) China Petroleum \& Chemical Corporation (also known as Sinopec) (China, $\$ 426 b n$ );

2) Royal Dutch Shell (the UK and the Netherlands, $\$ 388.37 b n$ );

3) Saudi Aramco (Saudi Arabia, $\$ 355.9 b n$ );

4) China National Petroleum Corporation (CNPC) (China, $\$ 346 b n$ );

5) BP plc (the UK, \$298.7bn);

6) Exxon Mobil (the US, $\$ 290.3 b n$ );

7) Total (France, $\$ 209.3 \mathrm{bn}$ );

8) Chevron (the US, $\$ 158.9 b n$ );

9) Lukoil (Russia, $\$ 115.2 b n)$;

10) Rosneft (Russia, $\$ 113.7 b n)$; and

11) Phillips 66 Company (the US, $\$ 111.4 b n$ ) (Note 3).

The other three Western juniors are Talisman Oil (Canada), Lundin Oil (Sweden) and OMV (Austria). 
The eleven major oil TNCs are richer than the developing countries in whose territories they operate. Their "market power" is an important factor in the critical assessment of their accountability for violations of human rights. The other factor is that the offender (the TNC) is not a natural person but a 'legal person' and the victim is the community in the particular zone of conflict the TNC operates. Three Ogoniland cases are worthy of note.

The first case is Wiwa v Royal Dutch Petroleum Company (Note 4). In this case, the plaintiffs who were members of the Ogoniland tribe of Nigeria sued under the Alien Tort Claims Act 1789 in the Southern District of New York Royal Dutch Shell Company (Shell) for their involvement in the arrest, torture and execution of Mr. Saro-Wiwa and eight other Ogoni elders who protested against the widespread environmental damage caused by oil and gas extraction and transport. The case was dismissed on forum non conveniens grounds (that an appropriate competent court may divest itself of jurisdiction if it appears that the action should proceed in another forum) and was settled out of court.

The second case is The Social and Economic Rights Action Centre (SERAC) v Nigeria (Ogoniland case) (Note 5). Article 24 of the African Charter on Human and Peoples' Rights 1981 provides peoples with a right to "a good satisfactory environment favourable to their development". In SERAC v Nigeria, the African Commission on Human and Peoples' Rights held, inter alia, that Article 24 of the African Charter imposes an obligation on the State to take reasonable steps "to prevent pollution and ecological degradation, to promote conservation, and to secure ecologically sustainable development and use of natural resources". In this case, the Ogoni people alleged that the Nigerian government directly participated in unsustainable oil development practices in Ogoniland in that the state-owned oil company had caused environmental degradation which included widespread contamination of soil, water and air, destruction of houses, burning of crops and killing of farm animals. The African Commission on Human Rights (an organ of the African Union) found that although Nigeria had the right to make use of a natural resource, Nigeria had breached its human rights obligation to Ogoniland because the level of pollution and human degradation was humanly unacceptable and made living in Ogoniland a nightmare.

The third, and relatively recent case, is Kiobel v Royal Dutch Petroleum Company (2013) (Note 6). In this case, the petitioners, former residents of Ogoniland, Nigeria, brought suit in the US District Court for the Southern District of New York against the respondents, Royal Dutch Petroleum Company and their subsidiary, Shell Petroleum Development Nigeria Ltd (SPDC). The petitioners alleged that the residents of Ogoniland had begun protesting the environmental effects of SPDC when Royal Dutch Petroleum recruited the Nigerian Government who, through its agents, crushed the demonstration by looting property and carrying out acts of violence such as rape, murder and forced exile which are crimes against humanity; and that the respondents aided and abetted those crimes. The petitioners alleged jurisdiction under the Alien Tort Claims Act instantiated above and requested relief under international law. The Second Circuit Court of Appeals decided that international law does not recognise corporate liability and dismissed the case. Although on appeal the US Supreme Court granted certiorari, the Court held that the acts which violated international law occurred outside the United States and the petitioners' suit was barred.

The three Ogoniland cases discussed above show clearly the legal and political hurdles to be surmounted in foreign courts where violations of human rights are brought against TNCs. The Ogoni people could not sue Shell in Nigeria because of the doctrines of act of state and state immunity (Note 7). A strong case will be made in the concluding remarks for the creation of an international court with jurisdiction over corporations in the interests of restorative or reparative justice.

\section{The Impact of TNCs on Indigenous Peoples}

Renewable natural resources are forests, fisheries and agricultural products. Forests are integral to the lives of indigenous peoples and are situated in their territories. They are the sources of softwood, mixed wood and hardwood; and joint ventures between TNCs and indigenous peoples such as Bloedel MacMillan and Weyerhauser in Canada have been successful (Sawyer and Gomez, 2012). However, unsustainable felling of timber by TNCs in the territories of indigenous peoples, especially in the rainforests, has contributed significantly to climate change, a global problem facing humankind that will not go away in a hurry (Salako, 2017). The other problems facing humankind are scarce resources, world hunger and the eradication of diseases. These problems could be solved by agrobiotechnology which is defined as "the application of new and promising scientific processes and techniques in the field of biotechnology to crop germplasm and novel use of plants, animals and microorganisms for the improvement of crops and livestock in terms of yield and quantity" (Francioni and Scovazi, 2006).

The feeding of the world population, expected to be 10 billion in 2050, by current extrapolation (Note 8), could 
be achieved by genetically engineered crops which ripen faster, mature quickly and last longer; and by hybridisation which introduces a plant breeding technique that is capable of providing more productive varieties and eliminating the possibility of saving or replanting seeds. Hybridisation leads to the commodification of germplasm which contains information which is the result of millennia of breeding and improvement by indigenous peoples based on traditional knowledge, that is, "all indigenous knowledge of the ecosystems historically and/or presently surrounding the indigenous people" including the three categories of folklore: (i) artistic folklore (marks of visual or performing arts); (ii) physical folklore (traditional knowledge of flora and fauna, medical knowledge and techniques of preparing natural substances); and (iii) spiritual folklore (indigenous religions, superstitions and customary laws)" (Koning, 1998).

With hybridisation came the commodification of germplasm and the germplasm which contained information from indigenous peoples became the property of agrobiotechnology TNCs, notable among which are Schering AgrEvo GmbH (or AgrEvo), Monsanto, Pfizer, Pioneer Hi-Breed and Zeneca. In return for their research on exploiting specific genetic characteristics, these TNCs perceived the acquisition of intellectual property rights in plant genetic resources as the only way of recouping the money spent on research and development. The problem is that agrobiotechnology and intellectual property rights are in conflict with the rights of indigenous peoples to their territories, resources, traditional knowledge and culture. The pertinent question is: what is the status of traditional knowledge of indigenous peoples under the existing international intellectual property law?

The preamble to the Convention on Biological Diversity (CBD) recognises the traditional knowledge, innovation and practices of indigenous peoples as relevant to the conservation of biological diversity and the sustainable use of its components (Note 9). Article 3 of the CBD contains an explicit reference to the principle of sovereign rights of indigenous peoples over their natural resources, and the importance of indigenous peoples for in situ conservation is recognised by Article $8(\mathrm{j})$ of the CBD which requires State Parties to respect and preserve innovation and practices of indigenous peoples relevant to conservation. Article 15 of the CBD authorises States to limit or place conditions on access to genetic resources, but this Article is subject to the discipline of the General Agreement on Tariffs and Trade (GATT)/World Trade Organization (WTO) and the Agreement on Trade-Related Aspects of Intellectual Property Rights (TRIPS Agreement) (Note 10). Although there was a consensus in the World Intellectual Property Organisation and TRIPS Council that TRIPS which was negotiated contemporaneously but in different fora with CBD should contain provisions for the protection of traditional knowledge, culture and folklore, it seems TRIPS passed this over in silence (Cottier, 1998). In view of the provisions of the international instruments instantiated above, how do we reconcile the intellectual property system with the indigenous biogenetic resources and traditional knowledge of indigenous peoples?

There are two options but both are problematic. The first option, the use of the mechanism of intellectual property protection, is fraught with difficulties. The problem with intellectual property rights is the fixation requirement. Inasmuch as traditional knowledge and folklore (as defined above) are unwritten and exist for centuries before they are abandoned or forgotten, the traditional intellectual property categories - copyright and patent - are limited in time and unsuitable for protecting indigenous biogenetic resources and related traditional knowledge. The second option is the sharing of benefits from the TNCs' exploitation of indigenous biogenetic resources and related knowledge with the indigenous peoples. This is inappropriate because of the principled and empirical objections. The principled objection is that not all indigenous peoples are willing to commodify their biogenetic resources and traditional knowledge and the empirical objection is that it is difficult to obtain informed consent from indigenous peoples. We are left with a third option - protection rooted in human rights which will be discussed below under the (in)efficacy of the mechanisms for regulating TNCs.

\section{A Critical Analysis of Corporate Social Responsibility}

The idea of corporate social responsibility evolved from a niche interest of environmentalists and from international human rights organisations to cut off the funding of armed groups in conflict areas and reduce the suffering of the civilian population with particular reference to Congo, Liberia, Sierra Leone and Sudan (Note 11). In the case of Sudan, Talisman Energy Inc (Canada) was persuaded by the Canadian government to sell its shares in an international consortium providing income for the Arab-Islamic government and prolonging the war against the Christians and the animists in South Sudan.

On the one hand, TNCs in the European Union in particular are interested in sourcing their minerals in a socially responsible way; on the other hand, some TNCs are averse to any form of internal rules that will make them accountable for their wrongs. Other TNCs, while accepting that some international legal standards should apply to them, opine that international law should not be transferred wholesale to them and would rather prefer international legal standards to serve as guide posts for corporate behaviour. 
What then is corporate social responsibility? The term "corporate social responsibility" is the notion that good behaviour is good business. The term is a compendious term for concepts such as "business ethics", "corporate accountability", "corporate citizenship" and "corporate sustainability" (Mares, 2018). The word "sustainability" used in the last mentioned concept was coined in the Brundtland Report which characterised as "sustainable" any development that "meets the need of the present generation without compromising the ability of future generations to meet their own needs" (WCED, 2005). "Corporate accountability" can be achieved through criminal legislation, transparency legislation and voluntary regulation by TNCs.

There are two aspects of corporate social responsibility: the political and the classical (Scherer and Palazzo, 2007). The conventional wisdom is that the role of businesses and, a fortiori, TNCs is to maximise their profits but there is a political perspective to businesses. Historically, TNCs have engaged in politics by exercising sovereign rights at the behest of States as in the case of the East India Company (VOC) and the Royal Niger Company, Chartered and Limited discussed in the Introduction; and they still collude with or aid and abet States as in the case of Royal Dutch Petroleum (Shell) and exploit non-renewable natural resources in neoliberal (developing) countries. The problem with economic actors engaging in politics is one of legitimacy: they are neither elected nor democratically controlled. The other aspect is the classical aspect: how do we make them accountable? Put differently, what is our conception of justice? Is it based on liberalism or cosmopolitanism or communitarianism?

\subsection{Liberalism, Cosmopolitanism and Communitarianism}

Sustainability or meeting the needs of the present without compromising the ability of future generations to meet their own needs raises questions of distributive justice. One conception of justice is the "common ownership of the earth" or the "common heritage principle" attributable to the seventeenth century philosophers such as Hugo Grotius, Samuel Pufendorf, John Locke and others who regard the earth as the common heritage of humankind. The view that God had given the earth to humankind is applied to the high seas, the ocean floor, Antarctica and outer space (Malanczuk, 1997; Trindade, 2010). But the quest for natural resources by European powers to benefit the home countries brought into focus philosophical issues which the European powers had to address.

Beginning in the 1970s, two liberal philosophers, Rawls and Nozick, who were social contractarians reflected on how the emergence of a post-Westphalian world has modified the moral responsibilities of governments, corporations and individuals. John Rawls in A Theory of Justice argues that justice as fairness can only be derived from the original position: a position of equality which corresponds to the traditional theory of social contract (Rawls, 1999a). In the original position, two principles of justice as fairness are proffered: (i) each person has an equal right to the most extensive scheme of equal liberties compatible with a similar scheme for all, and (ii) those who are disadvantaged or worse off are to be compensated (the difference principle) (Rawls, 1993 and 1999a). Rawls in The Law of Peoples uses the idea of "the original position" a second time with the parties now understood to be representatives of peoples to show how a World Society of liberal and non-liberal (but decent) peoples might be possible (Rawls, 1999b). In The Law of Peoples Rawls refused to extend "the difference principle" to a World Society of liberal and non-liberal (but decent) peoples because a world government to enforce such principle at the international level is not feasible. For Rawls, a world government would either be "a global despotism" or "a fragile empire torn by frequent civil strife as various regions and peoples tried to gain political freedom and autonomy" (Note 12).

Robert Nozick in Anarchy, State, and Utopia condemns Rawls's theory of justice as fairness as anti-meritocratic and provides a philosophical justification of neoliberalism. Nozick argues that individuals have rights and there are things no person may do to them (without violating those rights) (Note 13). Relying on Locke that a person acquires property when he mixes his labour with soil provided he leaves sufficient for others (the Lockean proviso), he propounds the entitlement theory of distributive justice. According to this theory, once a person's [or a TNC's] acquisition of property satisfies the three principles of just acquisition, transfer and rectification even the State has no right over it under its power of redistribution. For Nozick, only a minimal state can be justified. Any State more extensive violates people's rights (Nozick, 1974).

Cosmopolitanism whether political, which advocates the elimination or transformation of state borders, or ethical - which advocates what might be called a global sphere of moral standing - invokes the phrase "citizens of the world" to show that we must have equal moral standing. Cosmopolitanism is also divided into cosmopolitan liberalism (that the principles of distributive justice are acceptable when a person's prospects rather than the prospects of each society are taken into account), and cosmopolitan republicanism which emphasises the exercise of citizen sovereignty as a check to new forms of global authority not subject to democratic accountability. 
Embracing the insights in Rawls's theory of justice as fairness (outlined above) and transcending them, cosmopolitan liberals such as Beitz, Pogge and Buchanan argue that for the same reasons that parties agree to the difference principle in domestic society, the global principle should be the difference principle. For Pogge and Buchanan, the global basic structure comprises regional and international agreements such as GATT, WTO and various guiding principles, codes, norms, treaties and declarations which govern corporate social responsibility (Beitz, 1979/1999; Buchanan, 2000; Pogge, 2001a; and Pogge, 2001b).

Communitarians challenge the cosmopolitan liberals' emphasis on individual autonomy for closing of considerations of value that individuals and, a fortiori, indigenous peoples find in their culture, communal practices and traditions. Alasdir MacIntyre in After Virtue contends: "It is not just that different individuals live in different social circumstances; it is also that we all approach our circumstances as bearers of a particular social identity" (MacIntyre, 1981). In a similar vein, Charles Taylor, another communitarian opines that "since the free individual can only maintain his identity within a society/culture of a certain kind, he has to be concerned about the shape of his society/culture as a whole" (Taylor, 2001). While the state borders have only instrumental value from a cosmopolitan standpoint, they are morally defining from a communitarian standpoint (Hill, 2000).

Cosmopolitan republicanism, in the context of "crimes against humanity" with its focus on political tyranny, provides the conceptual tool for using the international political community as the addressee of human rights rather than States (Bohman, 2001 and 2004). A republican right claim has these three components: (i) the claim must be legitimate, (ii) the claim requires standing, that is, recognition as a person to make such claim, and (iii) the addressee, that is, the community in which one has status. The establishment of the International Criminal Court (ICC), discussed below, constitutes this political community as an addressee of such right claim in which individuals have legal status of citizens of the world. The problem, however, is that the ICC lacks jurisdiction over TNCs as juridical corporate entities. There is a plethora of internationally recognised frameworks and principles guiding corporate social responsibility and these will be discussed under three headings: (i) principles, declarations and guidelines, (ii) transparency laws, and (iii) self or voluntary regulation.

\subsection{Principles, Declarations and Guidelines}

The duty to promote and protect human rights in the Preamble to the Universal Declaration of Human Rights 1948 applies to "every organ of society" which includes TNCs (Note 14). The term "treaty" includes any international agreement in written form whatever its particular designation (treaty, convention, protocol, act, covenant, charter, declaration, concordat and memorandum of agreement) concluded by two or more states or other subjects of international law (Note 15). While the use of the appellation "treaty", "convention" or "charter" means that the instrument is binding, there are controversial candidatures such as declarations, agreements, guidelines and initiatives which may or may not be binding. Four of such instruments are worthy of note: (i) the OECD Guidelines for Multinational Enterprises (OECD, 2011); (ii) the OECD Principles of Corporate Governance (OECD, 2004); (iii) the United Nations Guiding Principles on Business and Human Rights (Note 16 ); and (iv) the International Labour Organisation: Tripartite Declaration of Principles Concerning Multinational Enterprises and Social Policy (Note 17).

The Organisation for Economic Co-operation and Development (OECD) Guidelines for Multinational Enterprises (hereinafter referred to as 'Guidelines') is unique among corporate social responsibility tools in its comprehensive nature. The Guidelines are recommendations which are non-binding principles and standards addressed by governments to TNCs operating in or from adhering countries. The Guidelines address all aspects of taxation, consumer interests, competition, science, technology, human rights and corporate behaviour. The recommendations on corporate behaviour include obeying domestic laws as the first obligation of enterprises; contributing to economic, environmental and social progress with a view to achieving sustainable development; and adhering to the good corporate practice promulgated by the OECD Principles of Corporate Governance (hereinafter referred to as 'Principles') (Note 18). Again, the Principles are not binding and are not aimed at detailed prescription for national legislation. They are evolutionary in nature: to be reviewed to meet the demands of a changing world and include the promotion of transparent and efficient markets which are consistent with the rule of law and clearly articulated division of responsibilities among different regulatory and supervisory authorities (Note 19).

The United Nations General Principles on Business and Human Rights stated corporate responsibility to respect human rights as one of its foundational principles and in order to meet this responsibility businesses should have in place policies and processes appropriate to their size and circumstances, and where businesses have contributed to adverse impacts, they should make amends through legitimate processes (Note 20).

The ILO Tripartite Declaration of Principles concerning Multinational Enterprises and Social Policy (MNE 
Declaration) offers guidelines on TNCs, governments and employers' and workers' organisations in areas of employment, conditions of work and life and industrial relations. The MNE Declaration, approved by the Governing Body of the International Labour Office at its $204^{\text {th }}$ Session in November 1977, has been amended recently to take account of the Paris Agreement 2015 concerning climate change and the OECD Guidelines for Multinational Enterprises (as revised in 2011) (Note 10). The MNE Declaration enjoins all parties to the instrument to respect the sovereign rights of States, to respect the Universal Declaration of Human Rights 1948 and its two offshoots, the International Covenant on Civil and Political Rights 1966 and the International Covenant on Economic, Social and Cultural Rights 1966 (section 8); to take effective measures to prevent and eliminate forced labour (section 23); and to develop a national policy to ensure the effective abolition of child labour (section 26). The principles, policies and standards promulgated in the MNE Declaration are exhortatory and aspirational (and not binding).

\subsection{Transparency Laws}

The purpose of transparency laws is two-fold, namely, to cut off the funding of armed groups in conflict areas to reduce the sufferings of the civilian population caused by human rights violations and to provide the least invasive method of shaping corporate behaviour. The Kimberley Process Certificate Scheme (KPCS) 2003 is the earliest effort to increase transparency in the chain of supply of minerals sourced by TNCs from conflict areas (Note 21). The KPCS focuses on "blood diamonds", and not the "3T + G" conflict minerals, and creates a certification process to accompany each exported shipment of rough diamonds. Although trade in rough diamonds is certified, certification is inapt for dealing with "resource curse" (the little economic growth generated in most developing countries with great natural wealth), and "resource privilege", that is, the power of de facto rulers of mineral-rich countries to effect legally valid transfers of ownership rights of their resources (Pogge, 2013). There are also problems with artisanal mining, discussed later, which is not within the purview of KPCS.

The Extractive Industries Transparency Initiative (EITI) 2003 goes beyond "blood diamonds" and promulgates global principles of transparency in oil, gas and mining. The EITI enunciates principles that describe how companies and governments can promote transparency and exhort companies to publish what they pay in taxes to mineral-rich governments; and the governments in turn to publish what they receive (Note 22). The problem with EITI, which is underpinned by the international rule of law, is that in international law sovereignty remains with States existing in a horizontal plane of sovereign equality and governments are not ready for the surrender of their sovereignty (Bishop, 1960-1961; Chesterman, 2008).

Two developments on both sides of the Atlantic are worthy of consideration. The disclosure laws enacted since 2010 are "name and shame" laws requiring TNCs to be transparent about their decision-making processes but not their conduct resulting in human rights violations. Two pieces of legislation - the California Supply Claims Act 2010 (the US) and the Slavery Act 2015 (the UK) require TNCs to disclose the presence of slavery and human trafficking in their supply chain and their efforts to eradicate them. The US Responsible Investment Burma Law 2012 was enacted to address the effects of new investment on the political transition in Myanmar (Burma) (Note 23). The Law required companies to report on eleven points including human rights policies and procedures, risk prevention and mitigation measures. This Law was in force from 2013 to 2016.

The Dodd-Frank Wall Street Reform and Consumer Protection Act 2010 (the Dodd-Frank Act) (Note 24) enacted in the US must be read conjunctively with its counterpart - the EU Council Regulation 2017/821 of 17 May 2017 (EU Regulation 2017) (Note 25). Section 1502 of the Dodd-Frank Act defines "conflict minerals" as "any other mineral or its derivatives determined by the Secretary of State to be financing the conflict in the DRC or an adjoining country". The objective of section 1502 and EU Regulation 2017 is to cut the link between conflict and trade in minerals and drain revenues from armed groups. Section 1502 directed the Securities Exchange Commission (SEC) to promulgate regulations requiring a person who files reports with the SEC to disclose whether any conflict minerals originating from the DRC was in their product. This disclosure requirement applies to companies that file reports with SEC limiting the scope of the rules to report issuers. Section 1504 of the Dodd-Frank Act aims to empower citizens in resource-rich countries to hold their governments accountable for wealth generated from natural resources in their States. Section 1504 expressly refers to EITI principles discussed above. The Dodd-Frank Act and the EU Regulation 2017 bristle with legal and practical problems. If the legislative intent of Congress was to reduce the use of conflict minerals thereby reducing the funding of armed groups, then the Congress used the wrong substantive law, namely, securities law to enforce reporting requirements that enhance transparency. The reporting requirement received a glancing blow in the decision of the US Court of Appeals, District of Columbia Circuit, in National Association of Manufacturers v SEC (Note 26). In this case, the Court held that the epithets "conflict free" or "not conflict free" 
on websites of SEC filings conveyed a moral responsibility on companies where their businesses only indirectly finance armed groups in the DRC and was a compelled speech which violated the First Amendment's right to companies' free speech. In spite of this judgment, companies are still required to audit their supply chain and report to SEC where the minerals are sourced but they are not obliged to report that their sourced minerals are "conflict free" or "not conflict free". And, what is more, most of the gold produced in the DRC is smuggled through neighbouring countries where they are smelted and sold to jewellers in the Middle East (Turner, 2013).

\subsection{Voluntary Regulation}

Voluntary regulation predates transparency laws. To facilitate exposition, one set of voluntary codes will suffice. The first voluntary codes of conduct, promulgated in 1976, are the Shell General Business Principles (Note 27). These codes are in three parts: (i) the core values of Shell such as honesty, integrity and respect for people; (ii) commitment to sustainable development: balancing short- and long- term interests and integrating economic, environmental and social considerations into business decision-making; and (iii) responsibilities to shareholders, customers, employees, business partners and society. From a corporate governance perspective, voluntary regulation may exacerbate the conflicts of interest between shareholders and stakeholders; from a legal perspective, it lacks effective enforcement mechanism and has been aptly described as "the fox guarding the hen house" (Baker, 1993).

\section{The (in)efficacy of the Mechanisms for Regulating TNCs}

The mechanisms for regulating TNCs are transparency laws, voluntary regulation and human rights litigation. The treaties, declarations and principles which govern corporate social responsibility are either binding as in the case of transparency laws such as KPCS, Dodd-Frank Act and the EU Regulation 2017 or non-binding as in the case of the OECD Principles, MNE Declaration and EITI and voluntary codes like the Shell Business Principles. Whether binding or not, the balance struck between imposing the whole corpus of international law on TNCs and doing nothing, that is, providing the least invasive mechanism for dealing with TNCs, leaves the civil population in developing countries in the hands of TNCs and they must depend on their goodwill for reparation.

Abuse of human rights by TNCs is regarded as a violation of the International Covenant on Civil and Political Rights 1966 (ICCPR). In the US Courts violations of the ICCPR activate the Alien Tort Claims Act (ATCA) as breaches of customary law. The ICCPR has been described as a 'toothless tiger' because the United States attached to its ratification five reservations, five understandings and one proviso (Carpenter, 2000). There are two formidable obstacles in invoking the jurisdiction of ATCA: the first is the doctrine of forum non conveniens and the second is the doctrine of judicial imperialism. In Wiwa v Royal Dutch Petroleum (Note 28), discussed above, the doctrine of forum non conveniens was invoked to dismiss the case.

In In Re Union Carbide Corp Gas Plant Disaster (Note 29), catastrophic damage was inflicted on a local population in a developing country. In this case, Union Carbide Corporation (Union Carbide), a New York firm owned 50.9 per cent of Union Carbide India Ltd (UCIL). UCIL manufactured the pesticides Sevin and Temik at the Bhopal plant at the request of and with the approval of, the Government of India. On the night of December 2-3, 1984 methyl isocyanate (MIC), a highly toxic gas, an ingredient in the production of both Sevin and Temik leaked from the plant for unascertained reasons and killed 2100 people (and it is still killing more people 36 years on). Over 200,000 people suffered injuries - some serious and permanent and others mild. Over 145 actions were filed in the United States District Court for the South District of New York involving approximately 200,000 plaintiffs. Union Carbide, the defendants, filed a motion to dismiss the consolidated action on the grounds of forum non conveniens (that American court is not the appropriate forum). The plaintiffs and an amicus curiae argued that the Indian legal system was inadequate to handle Bhopal litigation because of the absence of a tort law in India relating to high technology or complex manufacturing processes; and, in any case, the public interest is served when United States Corporations assume responsibility for accidents on foreign soil and abandoning that responsibility would injure the US standing in the world community and betray the spirit of fairness in the American character. The Court concluded by stating that to retain the litigation in the forum (i.e., New York) would be another example of imperialism in which an established sovereign inflicts its rules, standards and values on a developing country and dismissed the case on the grounds of forum non conveniens.

Union Carbide, in a settlement out of court, agreed to pay a final settlement of $\$ 470$ million in 1989 to the Indian government which, campaigners argue, provided $\$ 500$ each to 5000 victims and 570,000 exposed to the gas got nothing. In 1994, Union Carbide sold its subsidiary in India (UCIL) to a buyer who resold it to the India state of Madhya Pradesh. Union Carbide was then purchased by Dow Chemical Company in 2001 and the question of reparation became more complex.

Non-governmental organisations (NGOs) also intervene to curb abuses of market power by TNCs. NGOs have 
mobilised public opinion against human rights abuses by TNCs but opinions are mixed on the efficacy of such interventions. Some national jurisdictions permit civil litigation and criminal trials by NGOs against corporations. The European Centre for Constitutional and Human Rights (ECCHR) founded in 2007 and based in Berlin and the Argentinian Centre for Legal and Social Studies (CELS) established in 1979 have turned their attention to corporate responsibility for international crimes (Grosecu, 2019). The problem is that there is not enough practice for this to amounts to jus cogens (Simma and Alston, 1988-1989).

The right of indigenous peoples to their territories, resources and traditional knowledge is protected by Article 24 of the African Charter on Human and Peoples' Rights 1981 (ACHPR) (Note 30) and Article 11 of the San Salvador Protocol. Article 24 of the ACHPR protects the right to 'a general satisfactory environment favourable to [the] development' of the indigenous peoples as interpreted in SERAC v Nigeria above (Note 31). Article 11 of the San Salvador Protocol to the American Convention on Human Rights (Note 32) provides that everyone shall have the right to live in a healthy environment and State Parties shall promote the protection, preservation and improvement of the environment. These two instruments are complemented by Articles 24 and 25 of the United Nations Declaration of the Rights of Indigenous Peoples 2007 (UNDRIP) (Note 33). Article 24 provides that indigenous peoples have an equal right to their traditional medicines, health practices and conservation of their vital medicinal plants, animals and minerals. Article 25 provides that indigenous peoples have the right to maintain and strengthen their distinctive spiritual relationship with their traditional and otherwise occupied and used lands and territories. The problem is that although UNDRIP recognised the role played by NGOs as non-state actors, both traditional knowledge in particular and indigenous peoples' rights in general are state-centred: only states are charged with the duties to secure the human rights. Although litigation on human rights abuses by TNCs are fraught with problems discussed in the Ogoniland cases and In Re Union Carbide above, the fact remains that the human rights approach, coupled with regional arrangements for the enforcement by the rights of indigenous peoples to their land, biogenetic resources and traditional knowledge, provides the best strategy for reconciling the rights of Agrobiotechnology TNCs with the rights of indigenous peoples as recognised in international instruments such as ACHPR and UNDRIP.

Abuses of human rights, while serious, are not as heinous as crimes against humanity. The view of TNCs' criminal liability for aiding and abetting crimes against humanity ought to be critically assessed. In the Farben case (Note 34), I.G. Farben, an Interessen Gemeinschaft (IG or community of interest) with a monopoly of German chemical production at the commencement of World War II played a leading role in Hitler's war machine and could have been prosecuted before the International Military Tribunal at Nuremberg but was not. Of the 23 officers of the company charged with war crimes, crimes against humanity relating to the plundering and spoliation of foreign property and participation in slave labour programmes, 13 were convicted and 10 were acquitted. It has been suggested that the decision not to prosecute Farben as a juridical corporate entity was political, not legal. It is submitted that the reason is legal as neatly illustrated in Kiobel v Royal Dutch Company, discussed above (Note 35). In Kiobel, it was decided, inter alia, that international law did not recognise corporate liability for extrajudicial killings; crimes against humanity; torture and cruel treatment; arbitrary arrests and detentions; violations of the right to life, liberty, security and association; forced exile; and property destruction. But this case raises more questions than it answers. The pertinent questions are: (i) What is the status of corporations in international law? (ii) If international law addressed to corporate criminal liability were to be promulgated, where might criminal charges be brought? The traditional positivist theory of international law is that States are the only subjects of international law (Cassese, 2005; Crawford, 2019; and Salako, 2019). It is true that some jurisdictions such as the US and United Kingdom confer separate personality on corporations under criminal law but it is not "conclusive of autonomy vis-a-vis the state for the purpose of international law" (Note 36). National courts cannot try corporations for aiding and abetting crimes against humanity. This leads to the second question: If international law were addressed to corporate criminal liability, where might criminal charges be brought? There is a general consensus that the personal jurisdiction of the ICC is limited to natural persons (Crawford, 2019; Wouters et al., 2019). This is consonant with section 25(1) of the ICC Statute which provides that: "The Court shall have jurisdiction over natural persons pursuant to this statute." However, it has been suggested that corporate criminal liability could be imposed by amending or tinkering with the jurisdiction of the ICC (Chiomenti, 2006). This suggestion bristles with evidentiary challenges on such matters as the ascription of the acts of the authors of the crime (natural persons) to corporations (artificial persons) (actus reus), the intent to commit the crime by the corporation (mens rea), legal causation or attribution, and refusal of economic actors (corporations) to provide information. We are left with the proffered international court with jurisdiction over corporations. 


\section{Conclusions}

TNCs' exploitation of natural resources in developing countries is driven by their size and market power. The imperative for profit and neoliberalism put them in contact with acts of murder, torture, crimes against humanity and violations of human rights by rulers in developing countries exercising their resource sovereignty (Omeje, 2008). Any conflict with the local community arising from the exploitation of natural resources is resolved by the mechanisms of human rights litigation, voluntary regulation (a public relations exercise) and transparency regulation.

Human rights litigation is state-centred and limited by the doctrines of forum non conveniens and judicial imperialism which left the claimants in the Ogoniland cases to the goodwill of Royal Dutch Petroleum (Shell) and 570,000 claimants in In Re Union Carbide still without reparation 36 years after the ghastly accident. Neoliberalism not only triggers conflict as we saw in countries such as Chile, Bolivia, Bangladesh and the Philippines but also puts the control of businesses off-limits to popular deliberation and change. In spite of the trenchant critiques of the plethora of instruments promulgated on transparency laws, the neoliberal halfway house of non-invasive regulation is successful in dealing with "blood diamonds". But the fact remains that there is still a rebuttable presumption that "conflict minerals", and there are over 1100 of them, are often mined by artisanal miners and still being traded for profit by TNCs resulting in egregious human rights violations and crimes against humanity (Härkönen, 2018).

The recurring theme in all the cases discussed above is the lack of (or meagre) reparation. The opportunity to hold a corporation liable for war crimes and crimes against humanity was missed in 1948 in the Farben case. What is required in the twenty-first century is the establishment of an international court with jurisdiction over corporations in the interests of restorative or reparative justice (Ashworth, 1993; Zedner, 1994). The idea was mooted by the African Union in a proposal for a criminal section of the African Court of Justice and People's Rights, [a regional Court] (Jalal, Clarke and Nmehielle, 2019). This idea poses two conceptual problems which are surmountable. The first is whether retributive justice and reparative justice are antinomic, that is, whether they are claims which rival each other and whose goals must be in conflict (Zedner, 1994). It is submitted that they are not antinomic and in view of the Ogoniland cases and In Re Union Carbide, there is a need for paradigm shift in which "reparation" or "restoration" will take precedence over retribution; and this brings us to the second problem: what is the definition of a crime? The definition of a crime as "breaches of law as injure the community" is derived from the development of royal jurisdiction in England in the twelfth century which meant the direct restoration to the victim was sacrificed to securing the King's peace. In other words, the wrong was against society (Kenny, 1929). In the late twentieth century, there was a movement towards restorative or reparative justice which saw crime not only as a crime against society but as a dispute between the offender (in this case, the TNCs) and the victims which required solution (Zehr, 1985; Wright, 1996). The establishment of an international court with jurisdiction (shorn of the doctrines of forum non conveniens and judicial imperialism) over corporations and power to award damages by way of reparation against TNCs, with vast financial resources, is the only just remedy for victims of TNCs' illegal activities in the conflict regions.

\section{Acknowledgements}

Thanks to the anonymous reviewers for their informed and constructive comments.

\section{References}

Ashworth, A. (1993). Some Doubts About Restorative Justice. Criminal Law Forum, 4(2), 277-299. https://doi.org/10.1007/BF01096075

Bais, K., \& Huijser, M. (2005). The Profit of Peace: Corporate Responsibility in Conflict Regions. Sheffield: Greenleaf Publishing Ltd.

Baker, M. B. (1993). Private Codes of Corporate Conduct: Should the Fox Guard the Henhouse? Inter-American Law Review, 24(3), 339-433.

Beitz, C. R. (1979/1999). Political Theory and International Relations (pp.202 and 214-215). Princeton, New Jersey: Princeton University Press.

Bishop, W. W. (1960-61). The International Rule of Law. Michigan Law Review, 59, 554. https://doi.org/10.2307/1286235

Bohman, J. (2001). Cosmopolitan Republicanism: Citizenship, Freedom and Global Political Authority. Monist, 84(1), 3. https://doi.org/10.5840/monist20018412

Bohman, J. (2004). Republican Cosmopolitanism. Journal of Political Philosophy, 12(2), 336-352. 
https://doi.org/10.1111/j.1467-9760.2004.00203.x

Buchanan, A. (2000). Rawls's Law of Peoples. Ethics, 110, 706. https://doi.org/10.1086/233370

Carpenter, K. D. A. (2000). The International Covenant in Civil and Political Rights: A Toothless Tiger? North Carolina Journal of International Law and Commercial Regulation, 26, 1-55.

Cassese, A. (2005). International Law (2nd ed., pp.142-150). Oxford University Press.

Chesterman, S. (2008). An International Rule of Law? The American Journal of Comparative Law, 56, 331-361. https://doi.org/10.5131/ajcl.2007.0009

Chiomenti, C. (2006). Corporations and the International Criminal Court. In O. D. Schutter (Ed.), Transnational Corporations and Human Rights (pp. 287-312). Oxford: Hart Publishing.

Chomsky, N. (1999) Profit over People: Neoliberalism and Global Order. New York: Seven Stories Press.

Cook, A. N. (1964). British Enterprise in Nigeria. London: Frank Cass \& Co. Ltd.

Cottier, T. (1988). The Protection of Genetic Resources and Traditional Knowledge: Towards More Specific Rights and Obligation in World Trade Law. Journal of Economic Law, 1, 581-4. https://doi.org/10.1093/jiel/1.4.555

Crawford, J. (2019). Brownlie's Principles of Public International Law (9th ed.). Oxford: Oxford University Press. https://doi.org/10.1093/he/9780198737445.001.0001

Elias, T. O. (1967). Nigeria: the development of its laws and constitution. London: Stevens.

Faruque, M. O. (2018). The politics of extractive industry corporate practices: An anatomy of a community conflict in Bangladesh. The Extractive Industries and Society, 5, 177-189. https://doi.org/10.1016/j.exis.2017.11.009

Francioni, F., \& Scovazi, T. (Eds.). (2006). Biotechnology and International Law. Oxford: Hart Publishing.

Girvan, N. (1976). Corporate Imperialism: Conflict and Expropriation: Transnational Corporations and Economic Nationalism in the Third World. New York: Monthly Review Press.

Graff, J. (2004). Corporate War Criminals and the International Criminal Court: Blood and Profit in the Democratic Republic of Congo. Human Rights Brief, 11(2), 23-26.

Grosecu, R. (2019). Transnational Advocacy Networks and Corporate Accountability for Gross Human Rights Violations in Argentina and Colombia. Global Society, 33(3), 400-418. https://doi.org/10.1080/13600826.2019.1598947

Guzman, A. T., \& Sykes, A. O. (Eds.). (2007). Research Handbook in International Economic Law. Northampton, MA: Edward Elgar. https://doi.org/10.4337/9781847204233

Härkönen, E. (2018). Conflict Minerals in the Corporate Chain: Is Transparency the Solution to Human Rights Violations in Tantalum, Tin, Tungsten and Gold Supply Chains? European Business Law Review, 691-727.

Hill, T. E. (2000). Respect, Pluralism and Justice (pp. 81-82). Oxford: Oxford University Press. https://doi.org/10.1093/0198238347.001.0001

Hirsch, A. von, \& Ashworth, A. (Eds.). (2000). Principled Sentencing: Readings on Theory and Policy (2nd ed., pp. 300-360). Oxford: Oxford University press.

Hofmann, H., Schleper, M. C., \& Blome, C. (2015). Conflict minerals and supply chain: An exploratory study of multi-tier supply chains. Journal of Business Ethics, 1-53. https://doi.org/10.1007/s10551-015-2963-z

Jalloh, C. C., Clarke, K. M., \& Nmehielle. (Eds.). (2019). The African Court of Justice and Human and Peoples' Rights in Context: Developments and Challenges. Cambridge: Cambridge University Press. https://doi.org/10.1017/9781108525343

Kamminga, M. T., \& Zia-Zarifi, S. (2000). Liability of Multinational Corporations under International Law. The Hague, Kluwer Law International.

Kelly, M. J. (2018). Atrocities by Corporate Actors: A Historical Perspective. Case Western Reserve Journal of International Law, 50(1), 49-89.

Kenny, C. S. (1929). Outlines of Criminal Law (p. 3). Cambridge: Cambridge University Press.

Koning, M. (1998). Biodiversity Prospecting and the Equitable Remuneration of Ethnobiological Knowledge: Reconciling Industry and Indigenous Interests. Intellectual Property Journal, 12, 261-282. 
Kyriakakis, J. (2007). Corporations before International Criminal Courts: Implications for the International Criminal Justice Project. Leiden Journal of International Law, 30, 221-240. https://doi.org/10.1017/S0922156516000650

Leipziger, D. (2010). The Corporate Responsibility Code Book (2nd ed.). Sheffield: Greenleaf Publishing.

MacIntyre, A. (1985). After Virtue: A study in moral theory (2nd ed., p. 220). London: Duckworth.

Malanczuk, P. (2009). Akehurst's Modern Introduction to International Law (7th ed., pp. 207-208). London: Routledge.

Mantz, J. W. (2008). Improvisational economics: Cotton production in the eastern Congo. Social Anthropology, 16(1), 34-50. https://doi.org/10.1111/j.1469-8676.2008.00035.x

Mares, R. (2018). Corporate transparency laws: A hollow victory? Netherlands Quarterly of Human Rights, 36(3), 189-213. https://doi.org/10.1177/0924051918786623

McKern, B. (Ed.). (1993). Transnational Corporations and the Exploitation of Natural Resources. London: Routledge.

Nozick, R. (1974). Anarchy, State, and Utopia. Oxford: Blackwell.

OECD. (2004). OECD Principles of Corporate Governance. Paris: OECD Publishing. https://doi.org/10.1787/9789264106079-en

OECD. (2011). OECD Guidelines for Multinational Enterprises. Paris: OECD Publishing. https://doi.org/10.1787/9789264115415-en

Omeje, K. (Ed.). (2008). Extractive Economics and Conflicts in the Global South. Aldershot, Hampshire: Ashgate Publishing Ltd.

Patey, L. A. (2007). State Rules: oil companies and armed conflict in Sudan. Third World Quarterly, 28(5), 9971016. https://doi.org/10.1080/01436590701371728

Pogge, T. (2011). Politics as Usual: What Lies behind the Pro-Poor Rhetoric (pp. 47-48). Cambridge: Polity.

Pogge, T. (2001a). Rawls on international justice. The Philosophical Quarterly, 51, 246-253. https://doi.org/10.1111/j.0031-8094.2001.00228.x

Pogge, T. (2001b). Priorities of Global Justice. Metaphilosophy, 32, 6-24. https://doi.org/10.1111/1467-9973.00172

Rawls, J. (1993). Political Liberalism. New York: Columbia University Press.

Rawls, J. (1999b). The Law of Peoples with "The Idea of Public Reason Revisited". Cambridge, Mass.: Harvard University Press.

Rawls, J. (1999a). A Theory of Justice. Oxford: Oxford University Press.

Reyes, S. (2019). Conflict Free in the DRC. Santa Clara Journal of International Law, 17(1), 1-28.

Salako, S. E. (2017). Climate change, Environmental Security and Global Justice. International Law Research, 6(1), 119-131. https://doi.org/10.5539/ilr.v6n1p119

Salako, S. E. (2019). The Individual in International Law: 'Object' versus 'Subject'. International Law Research, 8(1), 132-143. https://doi.org/10.5539/ilr.v8n1p132

Sawyer, S., \& Gomez, E. T. (2012). The Politics of Resource Extraction: Indigenous Peoples, Multinational Corporations and the State. London: Palgrave Macmillan. https://doi.org/10.1057/9780230368798

Scherer, A. G., \& Palazzo, G. (2007). Toward a Political Conception of Corporate Responsibility: Business and Society Seen from a Habermasian Perspective. The Academy of Management Review, 32(4), 1096-1120. https://doi.org/10.5465/amr.2007.26585837

Simma, B., \& Alston, P. (1988-89). The Sources of Human Rights: Custom, Jus Cogens, and General Principles. Australian Yearbook of International Law, 12, 82-108.

Smith, J. H. (2011). Tantalus in the Digital Age: Coltan Ore, temporal dispossession, and "movement" in the Eastern Democratic Republic of Congo. American Ethnologist, 38(1), 17-35. https://doi.org/10.1111/j.1548-1425.2010.01289.x

Stiglitz, J. E. (2019). People, Power, and Profits: Progressive Capitalism for an Age of Discontent. London: Allen Lane. 
Tamm, I. J. (2002). Diamonds in Peace and War: Severing the Conflict - Diamond Connection. Cambridge, Mass.: World Peace Foundation Program on Interstate Conflict, Carr Centre for Human Rights Policy.

Taylor, C. (2001). Atomism. In S. Avineri, \& A. de-Shalit (Eds.), Communitarianism and Individualism (pp. 2950). Oxford: Oxford University Press.

Trindade, A. A. C. (2010). International Law for Humankind: Towards a new Jus Gentium (pp. 327-333). Leiden: Martinus Nijhoff. https://doi.org/10.1163/ej.9789004184282.i-728

Turner, T. (2013). Congo. Cambridge: Polity.

UNCTAD. (2008). World Investment Report 2007: Transnational Corporations, Extracting Industries and Development. New Delhi: Academic Foundation.

Vagts, D. (1970). The Multinational Enterprise: A New Challenge for Transnational Law. Harvard Law Review, 83, 739-792. https://doi.org/10.2307/1339838

WCED. (2005). Our Common Future (p. 145). Oxford: Oxford University Press.

Wouters, J., Ryngaert, C., Ruys, T., \& Baere, G. D. (Eds.). (2019). International Law: A European Perspective (pp. 396-402). Oxford: Hart Publishing.

Wright, M. (1996). Justice for Victims and Offenders: A Restorative Response to Crime (2nd ed.). Winchester: Waterside Press.

Zedner, L. (1994). Reparation and Retribution: Are They Reconcilable? Modern Law Review, 57(2), 228-250. https://doi.org/10.1111/j.1468-2230.1994.tb01934.x

Zehr, J. (1985). Retributive Justice, Restorative Justice. New Perspective on Crime and Justice, 4, 1-16.

\section{Notes}

Note 1. Salomon v Salomon \& Co. [1897] AC 22.

Note 2. S/RES/1173 (1998) [Angola] adopted by the Security Council at its $3891^{\text {st }}$ meeting, on 12 June 1998 , available at www.refworld.ong/docid/3b00f21018.html.

Note 3 . For the revenue of Saudi Aramco in 2018, see www.saudi-aramco-results-2017-208-summary-financial-pdf; and for other Oil TNCs, see https://www.offshore-technology-com/features/largest-oil-and-gas-companies-in-2018 (accessed on 3 March 2020).

Note 4. 226F 3d 99(2 $2^{\text {nd }}$ Circ. 2000), 96 Civ 8386, 2002 US Distribution, LEXIS 3293 (SDNY) 2002.

Note 5. AHPRR, No. 155/96 (2002).

Note 6. 133 S. Ct 1659 (2013).

Note 7. "Act of state" is an act of the Executive as a matter of policy performed in the course of its relation with other states and whatever it is municipal courts must accept it, as it is, without question" (Lord Wilberforce, in Buttes Gas \& Oil v Hammer No.3 [1982] AC 888, 932-3). It also includes an act done by an agent of the Crown whether previously authorised or subsequently ratified (Buron v Denman [1848] 2 Ex D 167). "State immunity" is defined as "a rule of international law that facilitates the performance of public functions by the state and its representatives by preventing them from being sued or prosecuted in foreign courts." See Crawford (2019:470).

Note 8. United Nations Population Fund, The State of the World (2009), p.25. Available at state_of_world_population.2009.pdf (accessed on 9 March 2020).

Note 9. The Convention on Biological Diversity (CBD) was opened for signature at the Earth Summit in Rio de Janeiro on 5 June 1992 and entered into force on 29 December 1993; available at cbd.int/doc/legal/cbd-en-pdf

Note 10. Trade-Related Aspects of Intellectual Property Rights (TRIPS Agreement), Annex 1C of the Marrakesh Agreement Establishing the World Trade Organization, signed in Marrakesh, Morocco on 15 April 1994; available at wto.org/english/docs_e/legal_e/27-trips_01_e.htm

Note 11. See Leipziger (2010:13) and Härkönen (2018: 691).

Note 12. See Rawls (1999b: 36).

Note 13. See Nozick (1974: ix). 
Note 14 . The Universal Declaration of Human Rights 1948, available at ohchr.org/EN/UDHR/Documents/UDHR_Translations/eng.pdf

Note 15. See Crawford (2019: 354-355).

Note 16. United Nations Guiding Principles on Business and Human Rights (UNGPs), available at ohchr.org/documents/publications/guidingprinciplesbusiness hr_en.pdf

Note 17. International Labour Organisation: Tripartite Declaration on the Principles concerning Multinational Enterprises and Serial Policy, 61 Official Bulletin ILO (1978), p.422, also available at http://www.ilo/organisation/public/english/85multi/tridec/index.htm

Note 18. See OECD (2011:17, 19 and 22).

Note 19. See OECD (2004: 17).

Note 20. Supra, note 16.

Note 21. UNCTAD (2007: 181).

Note 22. See Leipziger (2010: 350).

Note 23. See Härkönen (2018: 691-727).

Note 24 . Dodd-Frank Wall Street Reform Act 2019, available at congress.gov/111/plaws/pub1203/PLAW-111/pub1203.pdf

Note 25. [2017] OJL 1301, Arts 3-7 (Council Reg. 2017/82, OJL 130/1.

Note 26. 800F.3d 518 (D.C. Circ. 2015).

Note 27 . Shell General Principles, available at www.shell.com/home/content/aboutshell/ who_weare/our_values/sgbp/sgbp_30032008.html

Note 28. Supra, note 4.

Note 29. 634 F. Supp. 842 (S.D. N.Y. 1986).

Note 30 . African Charter on Human and Peoples' Rights 1981, available at achpe.org/legalinstruments/detail?id=49

Note 31. Supra, note 5.

Note 32. Additional Protocol to the American Convention on Human Rights in the Area of Economic, Social and Cultural Rights ("Protocol of San Salvador") adopted in San Salvador on 17 November 1988, available at oas.org/juridico/english/a-52.html

Note 33. United Nations Declaration on the rights of Indigenous Peoples (UNDRIP), available at un.org/ development/desa/indigenouspeoples/wp-content/uploads/sites/19/2018/11/UNDRIP_E_web.pdf

Note 34. See Kelly (2018: 68-69).

Note 35. Supra, note 6.

Note 36. See Crawford (2019:112).

\section{Copyrights}

Copyright for this article is retained by the author(s), with first publication rights granted to the journal.

This is an open-access article distributed under the terms and conditions of the Creative Commons Attribution license (http://creativecommons.org/licenses/by/4.0/). 